
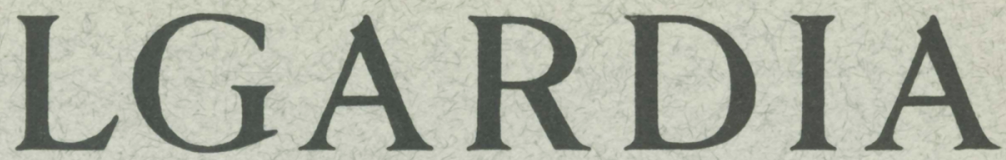

A Journal of Agricultural Science Published by the California Agricultural Experiment Station

\title{
CHEMICAL CONTROL OF FLLAMENTOUS GREEN ALGAE
}

\author{
L. S. JORDAN, B. E. DAY \\ and
}

R. T. HENDRIXSON 
Algae are often a serious problem in the management of water for agricultural, domestic and recreational purposes. Little information is available concerning the use of herbicides for control of algae.

Several herbicides were tested as potential algaecides in this study. Data are presented comparing their effectiveness.

Acrolein, diuron, copper sulfate and 2-amino-3-chloro-1,4-naphthoquinone were found to be effective, under proper conditions, for the control of Cladophora. Some of the difficulties involved in evaluating potential algaecides are discussed. 


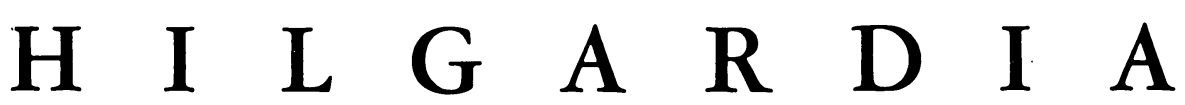 \\ A Journal of Agricultural Science Published by \\ the California Agricultural Experiment Station}

\section{CHEMICAL CONTROL OF FILAMENTOUS GREN ALGAE ${ }^{1}$}

\section{S. JORDAN, ${ }^{2}$ B. E. DAY, ${ }^{3}$ and R. T. HENDRIXSON ${ }^{4}$}

\section{INTRODUCTION}

Filamentous green algae are undesirable in both domestic and irrigation water. They form tangled mats and scums which retard flow, clog gates, weirs and channels, interfere with use of water areas for sports, and are unsightly in most situations. Effective and economic methods of control are desirable. When algaecides are used, consideration must be given to their immediate and long-term effects on the quality and usefulness of the water for domestic, agricultural, and recrcational purposes. In many situations where control of algae or other aquatic vegetation is desired, it is important to prevent injury to fish.

This paper presents data from trials undertaken to study the possible use of several herbicides for control of filamentous green algae. The toxicity of the herbicides to fish was also studied.

\section{Literature Review}

Copper sulfate is the only widely used chemical treatment for algae control. Its effectiveness is variable with species of algae and environmental conditions. Palmer (1956) found it to be toxic for 21 days to green algae growing in flasks. Derby (1954) reported that the dosage required to maintain control of algae in the Los Angeles water supply from the Owens River Valley varied from $1.0 \mathrm{ppm}$ in March to $0.8 \mathrm{ppm}$ in July and $0.6 \mathrm{ppm}$ in mid-August. Hale (1937) reported the dosages of copper sulfate required to control different genera of algae as follows: Cladophora: $0.5 \mathrm{ppm}$; Hydrodictyon: $0.10 \mathrm{ppm}$; Spirogyra: $0.12 \mathrm{ppm}$; and Ulothrix: $0.20 \mathrm{ppm}$.

Copper sulfate is less effective in hard than in soft water due to the precipitation of copper as the carbonate (Palmer, 1956). In soft waters, and at

\footnotetext{
${ }^{1}$ Paper No. 1347, University of California, Citrus Research Center and Agricultural Experiment Station, Riverside, California.

${ }^{2}$ Assistant Plant Physiologist, Department of Horticultural Science, University of California Citrus Research Center and Agricultural Experiment Station, Riverside.

${ }^{3}$ Associate Plant Physiologist, Department of Horticultural Science, University of California Citrus Research Center and Agricultural Experiment Station, Riverside.

${ }^{4}$ Laboratory Technician IV, Department of Horticultural Science, University of California Citrus Research Center and Agricultural Experiment Station, Riverside.
} 
the higher dosages required to control some species of algae, copper sulfate is often toxic to fish. Hale (1937) reported safe dosages of copper sulfate to fish as follows: carp, $0.33 \mathrm{ppm}$; goldfish, $0.50 \mathrm{ppm}$; and sunfish, $1.35 \mathrm{ppm}$.

According to Huddle (1958), monuron at $0.9 \mathrm{ppm}$ controlled filamentous algae for one week but lost its effectiveness within 2 weeks. Palmer and Maloney (1955) observed that $2 \mathrm{ppm}$ of monuron was toxic initially but became ineffective in 21 days. Bluegill and bass were not injured by $0.9 \mathrm{ppm}$ (Huddle, 1958) and goldfish were not injured by $14.9 \mathrm{ppm}$ (Oborn, 1954).

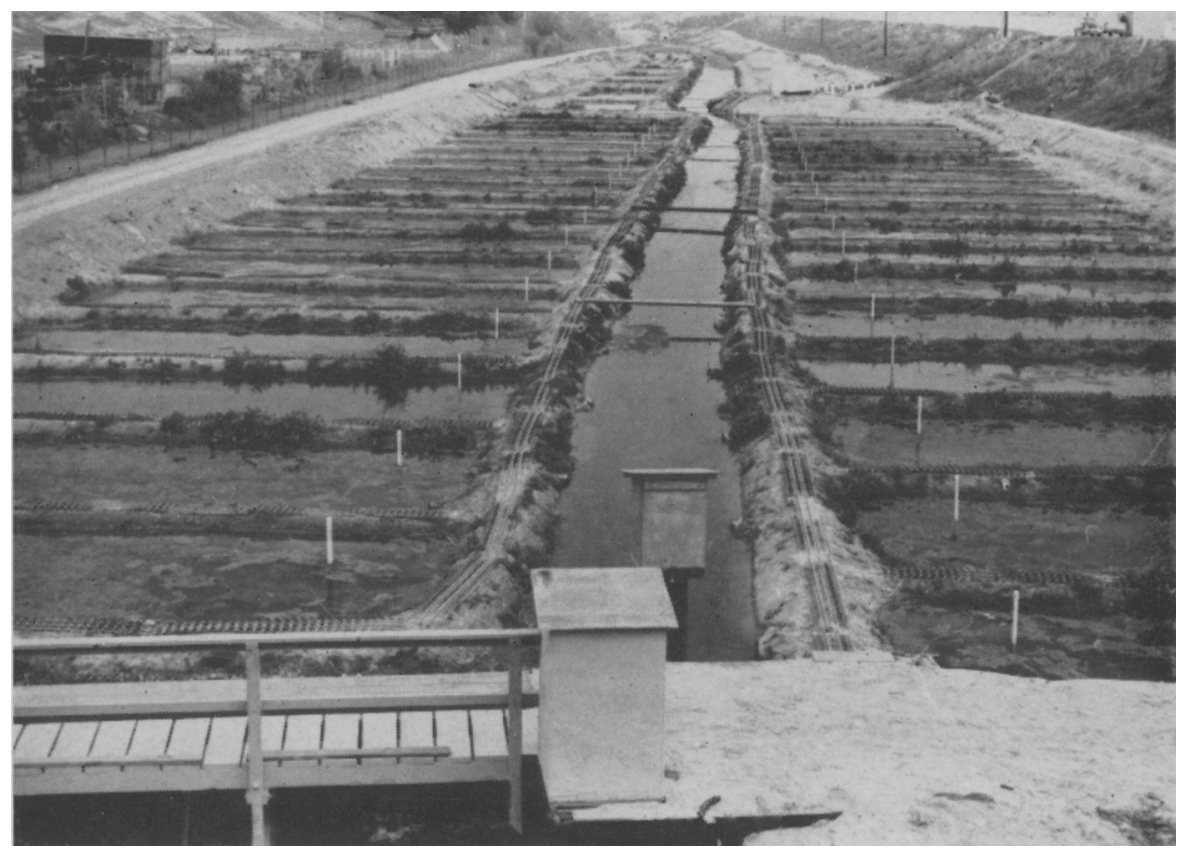

Figure 1. Ponds used for testing herbicides for filamentous green algae control.

Dichlone at $0.1,0.15$, or $2 \mathrm{ppm}$ has been shown to be effective for short periods (Huddle, 1958, Palmer and Maloney, 1955). Endothal at $100 \mathrm{ppm}$, 2,4-D at 2 to $10 \mathrm{ppm}$, and simazine at $6.7 \mathrm{ppm}$ have been reported safe for fish (NEWCC, 1959).

\section{Materials and Methods}

Experiments were conducted in a group of replicated ponds connected and fed by a central canal. These thirty-six ponds, 675 sq. feet in area, were constructed in sandy soil in the Rio Hondo river bed. Each pond contained approximately 7500 gallons of water when filled to a depth of 1.8 feet. Water depth was maintained at 1.8 feet except when percolation rates were determined at weekly intervals by closing the entry gate from the central canal and measuring the rate of fall of the water level. The predominant alga present was Cladophora. Figure 1 shows the construction and arrangement of the ponds. 
The following chemicals and formulations were tested: simazine (2-chloro4,6-bis (ethylamino)-s-triazine), 80 per cent wettable powder; atrazine (2chloro-4-ethylamino-6-isopropylamino-s-triazine), 80 per cent wettable powder ; atratone (2-methoxy-4-ethylamino-6-isopropylamino-s-triazine), $2 \mathrm{lb} / \mathrm{gal}$ emulsifiable liquid; prometone (2-methoxy-4,6-bis(isopropylamino)-s-triazine), $2 \mathrm{lb} /$ gal emulsifiable liquid; acrolein (acrylaldehyde), technical grade; 06K (2-amino-3-chloro-1,4-naphthoquinone), 50 per cent wettable powder; monuron (3-( $p$-chlorophenyl)-1,1-dimethylurea, 80 per cent wettable powder; diuron (3-(3,4-dichlorophenyl)-1,1-dimethylurea), 80 per cent wettable powder; copper sulfate, 94 per cent crystals; dichlone (2,3-dichloro-1,4naphthoquinone), 50 per cent wettable powder ; butoxyethanol ester of 2,4-D (2,4-dichlorophenoxyacetic acid), 20 per cent acid equivalent granular; and endothal (3,6-endoxohexahydrophthalic acid), $2 \mathrm{lb} / \mathrm{gal}$.

Rates of application of 2,4-D were on the basis of acid equivalent. Dosages of other chemicals were based on the active ingredient in the formulation. To permit comparison of degrees of response the chemicals were applied at dosages expected to produce only partial control of the algae.

Most of the treatments were made by adding the desired amount of chemical to one gallon of water and spraying it uniformly over the water surface with a compressed-air sprayer. Acrolein was applied under water through a polyethylene tube which was moved through the center of the pond from end to end while the chemical was being discharged. The 2,4-D granules were spread over the surface of the water and mats of algae. In one trial, copper sulfate was metered into the inflowing water through a needle-valve assembly to which a polyethylene tube was attached. Three replicate ponds were treated in the first two trials, and four replicate ponds in the last two of the four trials.

Prior to the first and second trials, the ponds were dried, cleaned of matted vegetation and clay, and leveled before filling. Between the second and third trials the ponds were dried and roto-tilled before filling. The ponds were not drained between the third and fourth trials. In the latter, the herbicides were sprayed directly on the water and the algae remaining from the previous experiment. Results were evaluated by visual estimation by two to seven persons working independently. Ratings were made on the day of treatment to obtain an initial estimate of population, and after one and two weeks on the basis of algae-free water surface. Ratings of 100 indicated complete coverage of the water surface by algae, and 0 indicated no algae present on the surface. Results were evaluated for statistical significance employing analysis of variance and multiple range tests.

\section{Results}

The results of the four series of treatments are shown in table 1 . The surface density of algae varied among the ponds at the time of treatment. Because of this variation, the data are presented as percentage of change of algal density after treatment with herbicides. For example, the average algal density for the control ponds on April 22 was 67.3, and after two weeks the average density changed to 70.7 ; therefore, the density at the two-week rating time was 105 per cent of the initial density on treatment day. The 
letters following density data (table 1) indicate statistical populations at the 5 per cent level of probability for vertical comparisons within individual trials only. Values in a column not followed by a common letter differ sig-

TABLE 1

EFFECT OF HERBICIDES ON DENSITY OF FILAMENTOUS GREEN ALGAE, WHEN APPLIED AT VARIOUS CONCENTRATIONS AT DIFFERENT TIMES OF THE YEAR

\begin{tabular}{|c|c|c|c|c|c|c|}
\hline \multirow{2}{*}{$\begin{array}{c}\text { Date of } \\
\text { treatment }\end{array}$} & \multirow{2}{*}{ Chemical } & \multirow{2}{*}{$\begin{array}{c}\text { Rate } \\
\text { (ppm) }\end{array}$} & \multicolumn{2}{|c|}{ Observed: 1 week } & \multicolumn{2}{|c|}{ Observed: 2 weeks } \\
\hline & & & Density* & Rank & Density & Rank \\
\hline \multirow[t]{11}{*}{ April 22, 1960} & Diuron...... & 3 & $13_{\mathrm{a}} \dagger$ & 1 & $142_{\mathrm{a}}$ & 9 \\
\hline & $\mathrm{CuSO}_{4} \ldots \ldots$ & 2 & $33 \mathrm{~b}$ & 2 & $89 \mathrm{a}$ & 1 \\
\hline & $06 \mathrm{~K} \ldots \ldots \ldots \ldots \ldots \ldots \ldots \ldots$ & 0.4 & $41_{\mathrm{bc}}$ & 3 & $148_{\mathrm{a}}$ & 10 \\
\hline & Acrolein....... & 3 & $55 \mathrm{~cd}$ & 4 & $106 \mathrm{a}$ & 4 \\
\hline & Control. . & . & $69_{\mathrm{de}}$ & 5 & $105_{\mathrm{a}}$ & 3 \\
\hline & Simazine.... & 3 & $81 \mathrm{e}$ & 6 & $159_{\mathrm{a}}$ & 11 \\
\hline & $\mathrm{CuSO}_{4} \ldots \ldots$ & 1 & $81_{\mathrm{e}}$ & 6 & $128 \mathrm{a}$ & 6 \\
\hline & Dichlone... & 0.3 & 87 ef & 7 & $120 \mathrm{a}$ & 5 \\
\hline & Monuron... & 3 & 90 ef & 8 & $132_{\mathrm{a}}$ & 7 \\
\hline & $2,4-\mathrm{D} \ldots$ & 11 & $90_{\text {e } f}$ & 8 & $140 \mathrm{a}$ & 8 \\
\hline & Endothal. & 1 & $105_{f}$ & 9 & $101_{\mathrm{a}}$ & 2 \\
\hline \multirow[t]{6}{*}{ June 13,1960} & Diuron. & 6 & $0.5 \mathrm{a}$ & 1 & $48 \mathrm{bc}$ & 4 \\
\hline & $\mathrm{CuSO}_{4} \ldots$ & $0.5 \ddagger$ & $2 \mathrm{a}$ & 2 & $0.4 \mathrm{a}$ & 1 \\
\hline & $\mathrm{CuSO}_{4} \ldots$ & 3 & $4 a$ & 3 & $29_{\mathrm{ab}}$ & 2 \\
\hline & $06 \mathrm{~K} \ldots \ldots$ & 0.5 & $12 \mathrm{a}$ & 4 & $46 \mathrm{bc}$ & 3 \\
\hline & Acrolein...... & 3 & $30 \mathrm{~b}$ & 5 & $\ldots \ldots$ & . \\
\hline & Control. & . & $56 \mathrm{c}$ & 6 & $70_{\mathrm{c}}$ & 5 \\
\hline \multirow[t]{9}{*}{ November 29,1960} & Diuron $\ldots \ldots \ldots \ldots \ldots \ldots \ldots$ & 2 & $104_{\mathrm{a}}$ & 1 & $132_{\mathrm{ab}}$ & 2 \\
\hline & $\mathrm{CuSO}_{4} \ldots \ldots \ldots \ldots \ldots \ldots \ldots$ & 2 & $109_{\mathrm{a}}$ & 2 & $107_{\mathrm{a}}$ & 1 \\
\hline & $06 \mathrm{~K} \ldots \ldots \ldots$ & 0.4 & $127_{\mathrm{ab}}$ & 3 & $136 \mathrm{ab}$ & 3 \\
\hline & Atrazine.... & 3 & $144_{\mathrm{ab}}$ & 4 & $141_{\mathrm{ab}}$ & 4 \\
\hline & Endothal..... & 3 & $151_{\mathrm{ab}}$ & 5 & $160_{\mathrm{ab}}$ & 7 \\
\hline & Acrolein... & 2 & $152 \mathrm{ab}$ & 6 & $159_{\mathrm{ab}}$ & 6 \\
\hline & Prometone... & 3 & $154 \mathrm{ab}$ & 7 & $152_{\mathrm{ab}}$ & 5 \\
\hline & Simazine.... & 3 & $160_{\mathrm{ab}}$ & 8 & $166_{\mathrm{ab}}$ & 8 \\
\hline & Control....... & .. & $199 \mathrm{~b}$ & 9 & $188_{b}$ & 9 \\
\hline \multirow[t]{9}{*}{ December 20, 1960} & Diuron... & 3 & $66 \mathrm{a}$ & 1 & $69_{\mathrm{a}}$ & 1 \\
\hline & Acrolein. & 4 & $84 b$ & 2 & $91_{\mathrm{ab}}$ & 4 \\
\hline & Prometone. & 5 & $90 \mathrm{bc}$ & 3 & $88 \mathrm{ab}$ & 3 \\
\hline & Simazine. . & 5 & $94 \mathrm{bc}$ & 4 & $109 \mathrm{~b}$ & 8 \\
\hline & Atrazine. . & 5 & 95 b c & 5 & $109_{b}$ & 8 \\
\hline & Atratone. & 5 & $95 \mathrm{bc}$ & 5 & $99_{\mathrm{b}}$ & 5 \\
\hline & $\mathrm{CuSO}_{4} \ldots$ & 3 & $97_{b c}$ & 6 & $84_{\mathrm{ab}}$ & 2 \\
\hline & Control... & .. & $100_{\mathrm{bc}}$ & 7 & $105 \mathrm{~b}$ & 6 \\
\hline & $06 \mathrm{~K} \ldots \ldots$ & 0.6 & $106 \mathrm{c}$ & 8 & $106 \mathrm{~b}$ & 7 \\
\hline
\end{tabular}

* Mean surface density of algae expressed in per cent of surface density at time of treatment.

$\dagger$ Letters a, b, c. . after mean values indicate statistical populations at the 5 per cent level. Mean values are statistically different if they are not followed by a common letter.

f Administered daily in the inflowing water.

nificantly. The herbicides are ranked in order of apparent decreasing effectiveness to permit comparison on a non-statistical basis. There were 11 rankings in the first trial, 6 in the second trial, and 9 in the third and fourth trials.

One series of treatments was made on April 22, 1960. Very little algal 
growth was present in the ponds. A second series of treatments was made on June 13, 1960 after the ponds had been drained, raked to remove dead algae, and refilled. A slight growth of algae was present. The third series of treatments was made on November 29, 1960. Pads of surface algae were forming. The fourth series of treatments was made on December 20, 1960 to algae remaining from the third trial. With the exception of endothal, each - herbicide was applied to the same ponds as in the third trial, but rates were increased in order to compare higher dosages. Atratone was substituted for endothal in the fourth trial.

During the first trial, diuron was significantly more effective than all other herbicides at the one-week observation time. Of the other herbicides only copper sulfate and $06 \mathrm{~K}$, in that order, significantly reduced the surface density of the algae as compared with the control. After two weeks there were no significant differences among the 11 treatment means.

One week after application in the second experiment (June 13,1960), there was no significant difference in algal control in ponds treated with diuron, copper sulfate, or $06 \mathrm{~K}$; but these compounds were significantly more effective than acrolein, which, in turn, significantly reduced the density of algae when compared with the controls. Two weeks after the second treatment, copper sulfate was the only treatment which significantly reduced the population of algae. The best results were obtained when copper sulfate was metered into the inflowing water.

One week after the third series of treatments, diuron and copper sulfate were significantly more effective than all other treatments. At the end of the second week, only the copper sulfate treatment prevented an increase in algal density.

During the fourth trial, diuron was significantly more effective than the other herbicides after one week, and resulted in a significant reduction in algae as compared with the controls after two weeks.

The relative ranking of some of the herbicides changed between the firstand second-week ratings and among the four trials. The rank of diuron changed from 1 at one week to 9 at two weeks in the first trial (April 22, 1960), from 1 to 4 in the second trial (June 13, 1960), from 1 to 2 in the third trial (November 29,1960), and remained unchanged as 1 in the fourth trial.

Copper sulfate at $2 \mathrm{ppm}$ changed from a rank of 2 at one week to 1 at two weeks in the first and third trials. Copper sulfate at $1 \mathrm{ppm}$ remained ranked at 6 in the first trial. During the second trial copper sulfate, maintained at $0.5 \mathrm{ppm}$, changed from a rank of 2 at the one-week rating to 1 at the twoweek rating. When applied to the surface at $3 \mathrm{ppm}$, the rank of copper sulfate changed from 3 to 2 during the second trial and from 6 to 2 during the fourth trial.

06K changed during the first trial from a rank of 3 after one week to 10 after two weeks; the rank changed from 4 to 3 during the second trial, remained at 3 during the third trial, and changed from 8 to 7 during the fourth trial. Acrolein ranked number 4 in the first trial, 5 in the second, 6 in the third, and changed from 2 to 4 in the fourth trial. Simazine dropped from 6 to 11 during the first trial, remained at 8 during the third trial, and 
changed from 4 to 8 on the fourth trial. Dichlone, monuron, and 2,4-D ranked lower than the controls during the first trial and were omitted from the last three trials. Endothal ranked 9 after one week and 2 after two weeks in the first trial, and changed from 5 to 7 during the third trial. Atrazine ranked 4 during the third trial and changed from 5 to 8 during the fourth trial. Prometone changed from 7 to 5 during the third trial and remained at 3 in the fourth trial. Atratone ranked 5 in the fourth trial.

The maximum, minimum, and mean percolation rates for the ponds on the treatment dates are shown in table 2 . The rates were determined for each individual pond and recorded as acre-feet per 24 hours. The rates varied from pond to pond and from day to day.

The survival of bluegill and goldfish in the treated ponds was observed 1 and 14 days after the third and fourth treatments were made. Acrolein was

TABLE 2

PERCOLATION RATES IN ACRE-FEET PER 24-HOUR PERIOD FOR PONDS TREATED WITH VARIOUS HERBICIDES FOR ALGAE CONTROL

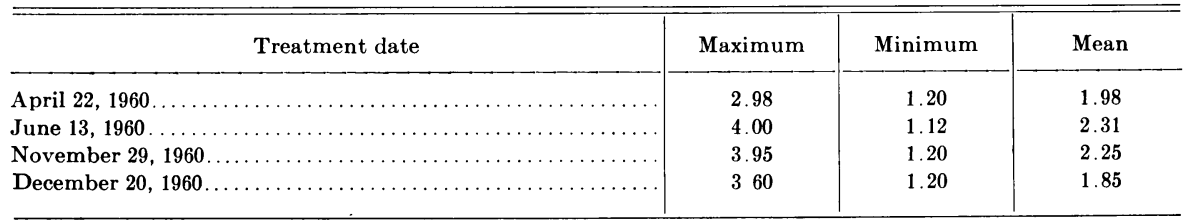

the only herbicide that injured the fish. When $2 \mathrm{ppm}$ of acrolein was applied, 50 per cent of both species were dead the next day. When $4 \mathrm{ppm}$ was applied, 98 per cent of the bluegill and 95 per cent of the goldfish died within 24 hours. Two weeks later, 97 per cent of the bluegill and all of the goldfish died when placed in ponds treated with $4 \mathrm{ppm}$ of acrolein.

\section{DISCUSSION}

Throughout the four trials, diuron and copper sulfate consistently decreased the density of algae more than the other herbicides. The best results were obtained when the copper sulfate in the water was maintained at $0.5 \mathrm{ppm}$. For no apparent reason, $06 \mathrm{~K}$ performed better in the first three trials than in the fourth. Acrolein was erratic throughout the four trials, sometimes performing well and sometimes poorly. It was evident from the pattern of injury to the surface pads of algae that this was due to inadequate distribution of acrolein throughout the water. Herbicides other than diuron, copper sulfate, $06 \mathrm{~K}$, or acrolein did not significantly reduce algal density. Apparently, either these chemicals were not herbicidal to the algae present in the tests, or the treatment rates were below the toxicity threshold.

The high percolation rates and consequent removal and dilution of the herbicides may account for the poor performance of some of the herbicides and for the general lack of residual control. Only in the second and fourth trials did any of the herbicides give significant control after two weeks.

These experiments point out some of the difficulties involved in evaluating potential algaecides. One difficulty is that populations of algae vary from 
time to time for reasons that are by no means obvious. Only after the third series of treatments was there an increase in average algal density in the untreated ponds during the first week. In the first trial, the surface density decreased in most of the ponds during the first week and increased rapidly during the second week. After the second treatment, density decreased in all ponds during the first week, with relatively little growth during the second week. After the third series of treatments, there was little change in algal density in most ponds between the first- and second-week observations. This information points up the importance of determining population fluctuation of algae in order to evaluate the effect of sublethal dosages of potential algaecides.

A second difficulty is that properly replicated bodies of water are seldom available for experimental work with algaecides. Results are usually evaluated according to population trends after treatments without adequate control areas to indicate population trends where there are no treatments. In this experiment, all of the treatments made on April 22, 1960, with the exception of endothal, appeared to have had some effect on algal population for the first week; yet, upon analysis, all but three were not statistically different from the control. All treatments made on June 13, 1960 appeared to have been effective after two weeks. Statistical analysis revealed, however, that only copper sulfate was significantly more effective in reducing algal population than no treatment. Under the conditions of the November 29, 1960 trials there was no reduction of algal density after one week in ponds treated with any of the herbicides. However, diuron and copper sulfate effectively retarded growth of algae during the first week, and copper sulfate, alone, was effective during the second week. Thus, in algaecide investigations, adequate control ponds are essential for comparison with treated ponds.

Another difficulty is the variation in the performance of individual herbicides. For example, diuron gave no residual control during the first two trials; but at an equivalent or lower rate gave residual control in the fourth trial and apparent but not significant residual control after two weeks in the third trial. Comparison of the density figures or rankings of the other herbicides listed in table 1 reveals other examples of variations in performance which cannot be explained by differences in treatment rates. These variations can probably be attributed to environmental changes which affected the growth of the algae and the performance of individual herbicides.

For control of algae, under conditions similar to those maintained during these trials, acrolein, copper sulfate, diuron, or $06 \mathrm{~K}$ would probably be effective in a repeat-treatment schedule if the chemicals were adequately dispersed in the water at rates adjusted to the time of year that treatments are made. The best procedure would probably be to meter the chemicals into the inflowing water in order to maintain adequate concentrations for control. 


\section{ACKNOWLEDGMENTS}

The authors acknowledge the assistance and counsel of Lauren D. Anderson and Ernest C. Bay. Appreciation is extended to A. A. Ingram and others of the staff of the Los Angeles Flood Control District for use of their facilities and to H. E. Pearson of the Metropolitan Water District for aid in identifying the algae.

\section{Summary}

Four series of experiments were conducted in replicated ponds to compare herbicides for control of filamentous green algae. The predominant alga present was Cladophora. The herbicides tested were simazine, atrazine, atratone, prometone, acrolein, 06K, monuron, diuron, copper sulfate, dichlone, 2,4-D, and endothal. Results were evaluated by rating algal density on the day of treatment and one and two weeks after treatment. Analysis of variance and multiple range tests were employed to determine statistical significance of the data.

During the first trial, diuron, copper sulfate, and $06 \mathrm{~K}$ significantly reduced algal density at the one-week rating, but not at the two-week rating, as compared with the control. During the second trial, diuron, copper sulfate, $06 \mathrm{~K}$, and acrolein significantly reduced algal growth one week after treatment, but copper sulfate was the only chemical which gave significant control at the two-week rating. In the third trial, diuron and copper sulfate were significantly more effective than other chemicals after one week, and copper sulfate was significantly more effective after two weeks. Diuron significantly reduced algal density at the one- and two-week ratings in the fourth trial. The other herbicides did not significantly reduce algal density because they were either not herbicidal to Cladophora or the treatment rates were below the toxicity threshold. There was a general lack of residual control of algae. This may have resulted from relatively high percolation rates in the ponds. Acrolein was the only chemical which killed bluegill or goldfish.

These experiments point out some of the difficulties involved in evaluating potential algaecides. One is the variation of algal populations. A second is that properly replicated bodies of water are seldom available. A third difficulty is the variation in the performance of individual herbicides. 


\section{LITERATURE CITED}

DERBY, RAY L.

1954. Methods of controlling aquatic growths in reservoirs. Jour. Amer. Water Works Assoc. 46:1141-1158.

Hale, Frank E.

1937. The use of copper sulphate in control of microscopic organisms. $35 \mathrm{pp}$. Nichols Copper Co., New York, N.Y.

HUdDLE, How ARd L.

1958. First progress report on evaluation of aquatic herbicides in Southern California waters, 1957. Calif. Dept. Fish and Game, Inland Fisheries Adm. Rept. No. 58-13. 11 pp. (Mimeo.)

Northeastern Weed Control Conference.

1959. Rept. of Research Coordinating Committee, Aquatics, Supp. to Proc. 13th Ann. Meeting. Pages 105-7.

OBORn, Eugene T.

1954. Control of aquatic weeds that impede flow of western irrigation water. Weeds $3: 231-240$.

Palmer, C. Mervin, and Thomas E. Maloney

1956. Evaluation of new algicides for water supply purposes. Jour. Amer. Water Works Assoc. 48:1133-1137.

Palmer, C. Mervin

1955. Preliminary screening for potential algicides. Ohio Jour. Sci. 55(1) :1-8. 

The journal Hilgardia is published at irregular intervals, in volumes of about 600 pages. The number of issues per volume varies. Subscriptions are not sold. The periodical is sent as published only to libraries, or to institutions in foreign countries having publications to offer in exchange.

You may obtain a single copy of any issue free, as long as the supply lasts; please request by volume and issue number from:
Agricultural Publications
207 University Hall
University of California
Berkeley 4, California

The limit to nonresidents of California is 10 separate issues on a single order. A list of the issues still available will be sent on request. 